\title{
Urban Identity in (Post)Modern Cities: A Case Study of Kharkiv and Lviv ${ }^{1}$
}

\author{
Oleksiy Musiyezdov \\ V. N. Karazin Kharkiv National University
}

\author{
Translated from Ukrainian by Ksenia Maryniak \\ Canadian Institute of Ukrainian Studies, University of Alberta
}

\begin{abstract}
This article aims to highlight the results of an empirical study of urban identity that was conducted by the author in Kharkiv and Lviv. The theoretical underpinnings of this research are based on the ideas of Manuel Castells and Zygmunt Bauman, as well as others. They assert that under the conditions of (post)modern society, groups which are involved in one way or another in the global post-industrial economy interpret cities and their relationship with them in a variety of ways-in other words, their definitions of urban identity vary. The author's hypothesis is generally confirmed that groups will interpret their connection to a city in distinct ways: representatives of different groups will differ in their interpretation of the question of what it means to be an "urbanite" or a "true [insert city name]-ian," in their ways of participating in the resolution of urban issues, etc. The unique features of the sampled Ukrainian cities (Kharkiv, Lviv) are described. The confirmation of the hypothesis serves as an argument in favour of considering urban identity in the context of an "imagined community." Under such consideration, a city comprises not a "local community" but an aggregate of groups that consider the city to be "theirs" and defend their "right to the city" based on their individual image of the world, which depends on their social, cultural, and economic conditions.
\end{abstract}

Keywords: Ukraine, city, urban identity, postmodern society, creative class.

\footnotetext{
1 This article is based on the results of research conducted in 2013-14 on the topic "Urban Identity in (Post)Modern Ukrainian Cities: Case Study of Kharkiv and Lviv" thanks to the generous financial support of the Canadian Institute of Ukrainian Studies at the University of Alberta (Mykola Klid Memorial Endowment Fund); the main research method was focus group interviews, with a total of 49 persons in both cities participating. [The original Ukrainian-language article was published in the journal Sotsiolohiia: teoriia, metody, marketynh, vol. 3, 2016, pp. 94-111. It is republished here in translation with permission. All original footnotes have been preserved. Explanatory notes are given in square brackets and identified as such in the footnotes. Bibliographic references have been reformatted according to MLA, as per EWJUS's style guidelines.]
} 
$\mathbf{W}$

hen social changes affect the definitions and self-definitions of individuals, groups, and societies, then urban identity-the perception and interpretation of their connection with a given city-becomes a common form of self-identification. There appears to be a significant lack of theoretical and practical research on this topic to date, and thus it would be worthwhile to fill the gap. This article aims to highlight the results of an empirical study that was based on the idea that in (post)modern societies, groups that are involved in one way or another in the global post-industrial economy interpret cities and their connection to them in various ways-that is, they have essentially different urban identities. Two cities were selected for comparison, Kharkiv and Lviv, both of them being large ${ }^{2}$ and with a significant proportion of the "creative class"; on the other hand, Lviv is usually presented as a "historical" city, while Kharkiv's image is that of an "industrial" city, which could influence the respective interpretations of their urban identity. ${ }^{3}$

\section{BACKGROUND}

Beginning in the later twentieth century, many researchers have gradually become aware of the fact that societies are acquiring characteristics that make them differ significantly from the "modern" societies described in classical sociological theory. This has prompted a lively search for new ways of describing the social world, as well as a rethinking of key issues and concepts in the field of social studies - in particular, those such as identity, territory, and city/urban. Modern concepts of identity emphasize that it is

\footnotetext{
${ }^{2}$ According to the State Statistics Service of Ukraine (http://ukrstat.gov.ua), in 2013 the population of Kharkiv was over 1.4 million, while that of Lviv was over 750,000. 3 Focus-group interviews were held in both cities with representatives of "cosmopolitan elites" and "local masses." In order to verify and refine the research hypothesis, four focus groups were planned, two in Kharkiv and two in Lviv; in each city, one group was to comprise representatives of the "cosmopolitan elites," while the second was to be made up of representatives of "local masses" (total of $4 \times 12=48$ persons). However, further consultations resulted in our decision to conduct an additional focus group in Lviv with persons whose occupational or educational characteristics place them among the unskilled and service occupations (that is, as representatives of the "local masses") but who have experience working abroad ("migrant workers")-a mobility criterion that places them among the "cosmopolitan elites." In Kharkiv this practice is much less common. Thus, focusgroup interviews were held as follows: "cosmopolitans" (8 persons) and "locals" (10 persons) in Kharkiv; and "cosmopolitans" (10 persons), "locals" (9 persons), and "migrant workers" (10 persons) in Lviv. Two additional interviews were conducted personally with "migrant workers," for an overall total of 49 persons interviewed.
} 
largely the product of independent efforts by individuals and groups to find themselves and their place, facilitated by information and communicative technologies (Baumeister; Castells, The Power of Identity; Giddens). Globalization in various aspects of human life has prompted discussions that reveal polarized views, from the "death of geography" to a "spatial turn in the social sciences" (Kononov; Trubina, "Povorot k prostranstvu"). In both cases, the essence of the matter is that physical space has ceased being practically the single determinant of social identity; instead, it has become more dependent itself on perceptions about it (which, in their turn, are subject to ongoing construction and reinterpretation). Given the fact that by now most of humanity is already living in cities, and that-under the influence of economic, cultural-communicative, and technological processes-cities per se are changing significantly compared to the classical capitalistic urban centre, urban identity (as the sense and awareness of oneself as a city dweller) has become one of the important "intersections" between territoriality and identity.

Particularly significant in this context is Castells's idea that modern society on the global scale is a "space of flows" (of information, finances, labour forces, and other resources), whose own developmental logic carves out certain "privileged" niches in physical space (first and foremost cities). Since urbanites are plugged into the "space of flows" in different ways, one can speak about the existence of certain "elites" that are cosmopolitan, not strongly tied to place, and about "masses" that lack the resources to change their location and thus are local (Kastel's [Castells], Informatsionnaia epokha and "Rekonstruktsiia sotsial'nogo smysla").

But this contrast is not absolute, as can be illustrated by referring to Zygmunt Bauman. While generally agreeing with Castells, Bauman says that both the so-called "elites" and the "masses" live in the same cities, and one way or another they create their own distinct urban identities. Moreover, as Sharon Zukin remarks, people with more cultural resources at their disposal are more active in ensuring that their city reflects their identity.

In other words, the "elites" as well as the "masses" seek out, create, formulate, and express meanings connected to place/city in order to answer questions about their own identity. However, we may suppose that the ways they go about it differ, and thus, the urban identities of these groups are probably different in content. Therefore, we may well ask what are the differences in urban identity between groups whose ties to their city as a local entity are different in nature?

Castells discusses differentiating groups based on a variable involvement in the "space of flows" that results from their having different levels of control over relevant resources-the most important of these include an advantageous profession in the post-industrial economy, a high level of professional qualifications, knowledge of languages, etc. It is helpful 
to identify these differentiated groups using the terminology of Richard Florida's ideas about the "creative class," which is mainly engaged in the work of "creative industries" - themselves a vanguard of sorts in the global post-industrial economy.

The term "creative industries" assumes a certain specificity in discerning what they encompass. For example, the UK government's Department for Culture, Media, and Sport (DCMS) ${ }^{[4]}$ defines them as "those industries which have their origin in individual creativity, skill, and talent, and which have a potential for wealth and job creation through the generation and exploitation of intellectual property" (Creative Industries Mapping); they include advertising, architecture, art, antiquities, crafts, film industry, design, fashion, publishing, software, music, theatre, television, and radio (Creative Industries Economic Estimates). Sometimes also included are the fields of scholarship and education, as well as "buildings and organizations that provide collective cultural products: museums, galleries, libraries, concert halls, and theatres that are either state-owned or privately owned" (Trubina, Gorod v teorii 254). Thus, based on these definitions, we may identify the main fields of interest of representatives of the "cosmopolitan elites" in the present study.

In his research, Florida mostly makes use of data from the Occupational Employment Statistics survey and the Bureau of Labor Statistics under the United States Department of Labor, which classify an enormous variety of occupations. He examines the creative class as being composed of two subclasses: a "super-creative core" and "creative professionals." The first includes professions in the field of programming and mathematics, architecture and engineering, natural and social sciences, education, mentoring, libraries, art, design, entertainment, sports, and mass media, while the second includes administrative professions, those in business and finance, law, health care (doctors and technical specialists), and those related to sales and sales management (Florida 355).

According to Florida, the specific point about the creative class is that it "makes money by designing and creating something new, and does so with a greater degree of autonomy and flexibility than the two other classes" (2324).[5] Such people are engaged in the post-industrial sector of the economy and, therefore, in the "global world." Although the majority of the creative class is not part of the upper class but rather the middle class (which has become the most influential and significant social group in developed

\footnotetext{
${ }^{4}$ [Currently called Department for Digital, Culture, Media, and Sport.-Trans.]

5 [The majority of the author's direct quotes are excerpted from translated sources, and therefore in this English translation they may not correspond exactly to the original source text; footnote numbers will not all correspond, either, due to added notes in the translation.-Trans.]
} 
countries), it can certainly be considered part of the "cosmopolitan elite" in the Castellsian sense, given that these types of people usually have weak ties to their workplaces, and in selecting places to live they pay more attention to life convenience rather than proximity to workplace.

The features of the creative class may be identified by consulting research which has determined that there are significant differences between those for whom cultural capital is the most important resource, on the one hand, and the "old bourgeois class" along with functionaries, managers, and administrators, on the other (Kutsenko). The creative, "professional" class differs from other classes not only, and not merely, by objective measures but also by a specific culture that is grounded in critical discourse and prioritizes upholding the significance of cultural capital. In particular, this applies to the development of a so-called ideology of professionalism, as a verification of their technical, intellectual, and moral superiority. Functionaries, managers, and administrators are affected much more by the distribution of power within employer organizations, and that is why they are typically extremely loyal to their organizations. For creative professionals, identifying with the organization is far less common, and instead they demand high levels of autonomy. That is why their values and political orientations are different: self-actualization, comfort, decentralization, absence of or minimal organizational and government restrictions or interference, left-liberalism, and focus on dialogue and solidarity rather than authority, status, and hierarchy-these could be called post-materialist values. According to Florida's research, for creative professionals the salaries, bonuses, benefits, or profit sharing are not as important as professional interests, responsibilities, scheduling flexibility, possibility of working at home, and a "thick" labour market (numerous competitive possibilities for employment in a single specialization). Their priority is "the possibility of active leisure and physical activity or extreme sports [...] they are attracted to a developed 'street culture' (clubs, bars, dancing, chamber music, and boutique art galleries), not the traditional cultural institutions like opera theatres or museums" (Gnedovskii).

Ukrainian cities have also been subjected to the influence of global processes that engender similar new groups. Certainly this process is not uniform in all cities, but for the large urban centres that are better connected to global-scale production and consumption processes, the general trend is indisputable. Moreover, the necessity of including Ukraine's cities in world markets has enlivened efforts to establish their own brands-in turn prompting public discourse on the evolving specifics of cities and urban identity in Ukraine. Simultaneously, the results of such reflections and discussions influence general public awareness of Ukraine's specificity and potential, although these ideas appear to be developing only in cities (Hlibovyts'kyi). 
For various reasons, the Ukrainian situation makes it difficult to assess those who Florida would call "creative professionals" as true representatives of the creative class. Quite a few of the Ukrainians in this group are often tied in very closely to local contexts-particularly legislation as well as local bureaucracy and corruption-beyond the bounds of which they are actually uncompetitive. Thus, adapting Florida's ideas about the creative class to Ukrainian conditions, I would argue for including the following groups in the "cosmopolitan elites" (those with mobility potential, i.e., weaker ties to locality/city): architects, designers, artists, IT specialists, world-class scholars, and journalists. Correspondingly, in the "local masses" I would include those who have limited possibilities for mobility: representatives of working-class occupations and the service industry. Therefore, pursuant to my research hypothesis, the differences between the answers of representatives of different groups should pertain not so much to the level of identification with their city as to how they interpret their connections to their city.

\section{MaIN RESUlts of THE STUDY}

The hypothesis concerning differences between the interpretation by "cosmopolitan elites" of their connections to their cities and that by "local masses" is generally confirmed. We shall first summarize the basic components of "connection to the city" that were manifested during the study, and then we shall examine specific differences in more detail.

\section{Components of "Connection to the City"}

In this study, connections to the city were observed not as an evaluation of certain possible parameters determined in advance, but rather as respondent descriptions of "true" residents of their cities and their own association with these descriptions. "True" city residents conformed to a greater or lesser degree to the following characteristics:

1. Emotional ties to the city, including pride in the city and local patriotism.

2. "Mentality," not as a scientific term but usually signifying a certain way or peculiarity of thinking, attitude to a given thing, understanding of cultural codes, etc., coalesced as a result of birth or lengthy period of living in the city, often in childhood.

3. Knowledge about the city, its history, and cultural features.

4. "Local culture" as an aggregate of certain traditions and behavioural peculiarities. 
5. A sense of responsibility for the city, which may be manifested as a result of feeling oneself to be a part of the urban community and/or of the city itself (the specific space, infrastructure, etc.), and may prompt various kinds of community activity.

In general, these components correspond, in part, to those singled out in Florian Znaniecki's classical work on urban identity. We note here that none of the points can be considered mandatory, and that the list was determined solely on the basis of aggregate responses by the focus group interviewees.

\section{Ways of Interpreting Images of "True" City Residents}

The differences occurred primarily in the interpretation of the features of a "true" city resident-a "true Lvivian" or "true Kharkivian"-as urban identity referents. The main difference between the "local" and "cosmopolitan" urban dwellers was that the former usually assess the city and its residents using psychological categories-open (or closed), friendly, and long-suffering (for "true Lvivians"), and uncomplicated, easy to talk to, active, intelligent, and work hard-play hard (for "true Kharkivians")—-while the latter more often reference urban culture.

"Locals" are more likely to take the characteristics of their fellow residents at face value and try to describe them. Meanwhile, "cosmopolitans" are skeptical about the existence of (objective) differences at all (e.g., "A Kharkivian is anybody who considers themselves to be one"), stress that one really cannot talk about a "true" or "typical" urban dweller, as they are not homogeneous (this view was more common among Kharkiv respondents), and also emphasize that prevailing stereotypes do not match reality (this was noted in Lviv):

- "There are certain typical images - they are satirical, caricatures";

- "I don't know whether a list of characteristics can be drawn up, and then to say that this is a true Lvivian, because there is no such thing in reality";

- "What can be said about a Lvivian? Probably the main thing is that he is expected to be [my emphasis-0.M.] Ukrainian, to speak Ukrainian, to wear an embroidered shirt."

\section{Interpretations of the Specificity of a City and Its Residents (Kharkiv vs. Lviv)}

Concerning the image of a city and its "true" residents, there is a significant difference between Kharkiv and Lviv. Being a tourist city, Lviv has long had 
its "myth of the city"[6] —among other things, that it is a tourist attraction, a façade generally for show (which inevitably also affects the selfidentification of its residents). The image of a "true Lvivian" is best described in two discourses: ${ }^{7}$

- "The nationalist-traditionalist": an [ethnic] Ukrainian, respects his elders, family, and traditions (conservatism, clericalism) as well as folklore (embroidered shirts) and piety (churchgoer); according to one respondent, a "true Lvivian" can be described with the triad of where they devote their energies, namely, "Garden plot-Church-[vigilance against the enemy] Muscovite";

- "The urban intelligentsia": people who have a "metro" lifestyle (cafes, restaurants, theatre), have a distinctive language ("Lviv argot") and culture (e.g., "Lviv coffee"), and feel a responsibility toward their city.

Interestingly, the ("cosmopolitan") respondents themselves remarked on a contradiction between these images, namely, that Lvivians are individualists, on the one hand, but they also care about "what will people say," on the other.

Kharkiv does not have such a "myth of the city," and its varied images often contradict one another-for example, "city of culture" and "city of hucksters" ("Kharkiv is a city of contrasts"). As I have noted in previous works (Musiyezdov, "Identyfikatsiia Kharkova"), this is associated with the absence of a necessity, and corresponding experience, of constructing an image of the city for oneself, and also with the significant socio-economic and cultural differences among its residents.

Interestingly, both groups of Kharkivians ("cosmopolitans" and "locals") listed "ambition" and "pretensions" as characteristics of their urban identity: "In Kharkiv it's important to be successful, important to be recognized, not invisible in the crowd but distinctive in some way, to attract attention; it's important to be valued" ("cosmopolitans"). At the same time, these pretensions are not always grounded in reality, and thus may be perceived as unjustified-like "putting on airs" ("locals").

They also emphasize that the heterogeneity of the city allows the possibility of finding and interacting within one's own circle, achieving recognition there:

Kharkiv is very varied. On the one hand, you can go to the Barabashova market and around Moskalivka district to check things out, what's going on, how people are relaxing. Or you can even take in a unique concert or a

\footnotetext{
${ }^{6}$ [An aggregate of various real and imagined stories or perceptions about a city that together create a particular aura, atmosphere, etc.-Trans.]

7 The existence of such images is described, in particular, in Sereda.
} 
unique lecture or poetry reading, like, you know ... back in the early twentieth century, somewhere in Paris, if you happened by chance to go in some decadence poetic salon.

At the same time, a lack of recognition beyond one's circle does temper people, so at least the creative ones are able to fulfill themselves fairly successfully in other cities:

I consider Kharkivians-especially the creative ones-to be very strong in the sense of having survived and being engaged in the cultural life of Kharkiv will not be defeated anywhere for lack of money or lack of support. Such people, they do their thing no matter what.... Here in Kharkiv, it's like Brazil, you know: a lot of great soccer players, but all of them are making money in Europe. It's the same in Kharkiv-a type of training ground, that's how most people perceive Kharkiv. They believe that Kharkiv is pretty cool, and it seems to produce an awful lot of creative people ... but the trick is to leave here early. This opinion is widespread, and mine is about the same. As for mentality, like I said, Kharkiv is a very interesting creative city in the sense that sometimes it's super-cool here, and sometimes it's very problematic. And sometimes it varies like that ten times a day. I'd say that this is the essence of the creative Kharkiv mentality: people from here, they are ... very tough ... they've achieved things in this city of theirs, so .... Certainly this applies not only to creativity but also, for sure, business and other matters, too.

Compared to the image of a true urban dweller, Kharkivians generally consider themselves to be rather typical. However, as mentioned above, the "cosmopolitans" are often doubtful that a single "type" of city resident exists. As a matter of fact, indeed several types of Kharkivians were identified, associated with the city's districts. Such a heterogeneity of residents can sometimes interfere with indentifying oneself as a Kharkivian; although the city can be familiar, understood, and comfortable in one aspect, it can be absolutely unfamiliar, incomprehensible, and uncomfortable in another ("an odd city"):

It's hard for me to connect to it, because many different people live here who share certain values that aren't mine at all, but they live with me in the same city and, like, they do things in it, too .... I consider myself part of a specific social group, but not of the city.

The respondents reflect the connection of residents not as much with the city as a whole as with "their" districts, where quite distinct social, neighbourly, daily transactional, and other ties are formed. These, in turn, allow us to characterize Kharkiv as a "provincial city." 8 Thus, the Kharkiv

8 Interestingly, the district that "cosmopolitan" Kharkivians most identify themselves 
discourse ("myth of the city") produced by the interview respondents is founded in part on a perception of the city's variety and heterogeneity, and also of its provinciality - which, to be sure, contradicts to a certain extent the widespread slogan of Kharkiv as the "first capital" of Soviet Ukraine; let us keep in mind, however, that it is the "cosmopolitan" respondents who are critical of this image, even regarding it to be harmful, as it causes narcissism as opposed to a drive for development.

Comparing their city with other cities, the respondents focus, of course, on their own experience, which is different for the residents of each of the two cities. There are also differences between the cities to which their respective city is similar. For Lviv, this means mostly Polish and Galician cities (Krakow, Wrocław, Lublin, Gdańsk, Ivano-Frankivsk, and Ternopil). For Kharkiv the answer is somewhat more variegated-comprising a set of Soviet or post-Soviet cities such as Dnipro (formerly Dnipropetrovsk) and Donetsk (until $2013^{\circ}$ ), as well as "cosmopolitan cities" and "cities of contrast" (Istanbul, Berlin, Warsaw) and a third set of cities with a "secondary capital complex" (Saint Petersburg). Among the mentioned cities were also some that were similar to both Lviv and Kharkiv-Odesa and Saint Petersburg. ${ }^{10}$ In sum, it could be said that overall the emphasis for Kharkiv is its "cosmopolitan" aspect, whereas for Lviv it is the "local" aspect.

\section{Connection to the City}

In all groups, habit featured as the main factor in one's connection to their city: a place or places of memories, an "intimate topography." However, the "cosmopolitan" respondents perceived their city through the prism of their occupation and their (active) leisure or cultural life - that is, to what extent the city is convenient for facilitating their personal preferences and their desired lifestyle: "I would like to associate myself with this city, but for a number of reasons I cannot do so .... There are no possibilities for professional growth, ... my specialization is not in demand to the extent that it should be."

Moreover, what is most desirable for them is an urban lifestyle, with its rhythms, excitement, etc. For them, the city they live in is by their own

with might not be the one they actually live in. This is not so strange when one considers the suburbs; the population of Saltivka district, for example, is nearly 400,000 .

9 The interviews were conducted in July-August 2014, and respondents noted that they cannot assess [Donetsk] currently [having left the city because of the war].

10 The latter confirms that not only Kharkiv but also Lviv evidently has a "capital city complex," being known as the capital of Galicia and the capital of the "Ukrainian Piedmont" (see, e.g., Musiyezdov, "An Identity of Kharkiv"; Zakutii). 
choice, not a given: "My work is absolutely the same in any place on the planet where there is electricity and the Internet. And an ATM. ATM's also required."

Nevertheless, the potential readiness or unreadiness to change one's place of residence is attributed to ordinary circumstances, while the change itself is perceived through the prism of expending extra effort:

If you live long enough in a city, after a certain time you accumulate stuff no matter what. In the sense of friends, acquaintances, your favourite pubsbut really it's much more than that.... The apartment you live in, the school your kid goes to-all these things attach themselves to you. Then to change it all, it involves breaking up a lot of things.

Meanwhile, in describing their connection to the city, "locals" almost never mention their occupation; rather, the focus is on a particular traditionality (more so in Lviv: "I try not to litter," "going to the [medieval city] centre," "teaching children [about the history of the city and good manners]") or on the everyday social and physical environment, mostly neighbourhood matters (more so in Kharkiv: "everyone in your neighbourhood says hello"). We may assert that in both cases, Lviv and Kharkiv- "local" respondents live in conditions somewhat similar to the classical urban villagers, at least insofar as the importance of local community to them (Gans). Research has generally shown that a person's involvement in neighbourhood life depends on specific factors. Namely, the more a person is in contact with friends, acquaintances, colleagues, relatives, and people with common interests, etc., the less important neighbourhood ties are to him or her. More educated city dwellers, youth, and men are prone to spending their time outside the home more often, while the neighbourhood is more important to retired persons and housewives. Research also shows that representatives of the working class are more interested in neighbourly ties than representatives of the middle class are (Vagin).

\section{The "City Dweller" Experience}

Both "local" and "cosmopolitan" respondents say that the main advantage of a city per se is its infrastructure, or "access to civilization." The "cosmopolitans," as expected, describe a desirable city (therefore theirs, since living there is by their own conscious choice) very similarly to the requirements ascribed to cities by representatives of the creative class (Clark; Florida; Gnedovskii):

Being a city dweller means having the possibility to "ride a bicycle with a 
hard fork and not get poked in the arm"; being a city dweller is having a choice of bars, clubs, and cinemas-whatever you prefer on any particular day; it's the possibility to choose your job from at least ten options, not one; and overall, to be able to spend your money in a large variety of places (Kharkiv);

It means that there's cultural resources available ... cinema, theatre, other cultural events-could be festivals, learning programs, lectures-not related to work (Lviv);

Being a city dweller means that next to you are quite a few unfamiliar people, and you feel comfortable in this common environment, and you are interested in being next to such people not known to you .... And being a city dweller, it seems to me, is above all being willing to accept that there are different people around you, and being willing to communicate with them-not, even, always in a pleasant way (Kharkiv).

For Kharkiv "cosmopolitans," too, a significant advantage is being able to avoid unpleasant contacts - which is rather common for large cities:

Here in Kharkiv, if there's a person around with whom I don't want any interaction, I can avoid meeting them. I can walk down other streets or not respond to telephone calls, of course, but most important is not to go to the coffee shop they like to frequent and to walk down other streets-it's easy. In a small town, if there's a person who's awkward to talk to, it's practically impossible to avoid meeting them.

For the "locals" (especially in Kharkiv), they often wish they could live in the country or in the suburbs-far from the urban noise, crowds of people, and intensive urban life and as close as possible to nature:

I would like to switch my apartment for a house in the suburbs ... I'd like to live in an environmentally cleaner area (Kharkiv);

The number of people in the city is exhausting .... So many neighbours, so many people .... Sometimes I simply want to be alone (Kharkiv).

But at the same time, they are not prepared to reject the urban infrastructure or lifestyle: "I'm not adapted to working in the countryside" (Lviv).

However, younger respondents and those who live downtown ("locals") do not agree, and in this they are more like the "cosmopolitans": "Living downtown, your whole existence is downtown-you go out there, and you work there.... It has more potential for personal development, which is very important for large cities" (Kharkiv). 


\section{Being Involved in the Resolution of Urban Issues}

In the context of our study it is interesting to review the answers to questions about who should be solving urban problems, and how the respondents themselves participate in this. Both groups-the "cosmopolitans" and the "locals" - place the responsibility on the municipal government and also on residents themselves.

However, concerning joint actions with the authorities, the former talk in terms of "pressure" (pickets, letters, appeals, petitions), while the latter talk of "complaints":

Periodically I try to monitor the information about public hearings, and take part ("cosmopolitan");

The main problem is corruption of the bureaucrats, and the government should be solving it, with frequent "kicks in the behind" on the part of the public ("cosmopolitan");

The higher administration is to blame-they don't care about the city at all ("local");

[Someone should] photograph [the problems] and send them to the mayor ("local").

At the same time, the "cosmopolitan" respondents propose a larger range of independent participation in solving municipal problemsvolunteering, fundraising, cultural and charity events, exhibitions, lectures to promote responsible city dwellers, etc. Meanwhile, the "locals" usually appeal more to traditions and moral responsibility-by "striving not to litter," "commenting," "participating in cleanups," etc.

For Kharkiv's "cosmopolitan" respondents, a particularly acute issue is their municipal government in general, and especially the Kharkiv mayor. The main problem is that the city authorities ignore the law-all other problems are minuscule by comparison. Another important problem is too much bureaucracy, which makes it impossible for the public not only to influence government decisions but also to carry out their own initiatives as well: "I'd gladly participate in the crowdfunding of municipal projects, but only for local private initiatives, because municipal crowdfunding is impossible here."

At the same time, it is noted with regret that most residents of Kharkiv are happy with the municipal government, so any kind of public campaign is rather dubious as to its potential effectiveness: "I'd like to feel myself in the majority, not the minority, on issues that are important to me." 
The "Migrant Workers" Group As an Exception

As mentioned above, to clarify the study results, interviews were also held with "migrant workers," who demonstrate certain similarities to both other groups. In describing their own connection to the city, like the "locals," they do not mention their occupation and are more passive when it comes to solving municipal problems. At the same time, concerning other questions they are shown to be more similar to the "cosmopolitans." This latter case is probably related to their specific experience-which includes comparing people in various places where they have lived for a time. In addition, a large proportion of the "migrant workers" are younger people, who oftenregardless of their current working-class occupation or job in the service industry-have a college or university education, or have completed professional training having to do with intellectual work. For some, their current status has come about as a result of their desire for personal development, to find themselves, etc. For others, it is beyond their control, a result of not being able to work in their specialized area. In our study, for example, such people included a communications engineer who was working as a boiler operator and a person with two post-secondary degrees who was working at a chocolaterie.

Like the "locals," the "migrant workers" also describe "true Lvivians" in psychological terms:

Such people are always friendly; if your face is tear-stained, they will always ask you what's the matter, or if you're tired in the streetcar, an older woman will say "sit, you've been working all day." They are very kind people, involved and cultured.

Older "migrant workers" are also similar to the "locals" in their preference for tradition when describing "true Lvivians" (especially those of the same age):

They value their job and contribute a lot to it. As a rule, they are pious and go to church. They respect their elders. They cherish our folk traditions, especially the embroidery .... For example, a true Ukrainian of my age will have a portrait of [national bard Taras] Shevchenko in his home, and since we have obtained independence, a true Ukrainian will have our national flag in his home, too.

But they also show that "true Lvivians" are not all the same, and perceptions of them are often stereotypical:

A true Lvivian is probably watering their garden plot every day, going to the Greek Catholic Church every Sunday, and using a wooden saw after church 
services to dismember Muscovites, because he's got the time and motivation to do so. But seriously, people are all different, and in principle it's clear that life in any given city-especially in a city like Lviv, which has, let's say, it's own particular special flair-will leave its [mark], but it will make its mark differently on each group. That is, different age groups will be different from one another, and different social groups will also be different from one another.

Analyzing the interviews with "migrant workers" leads us to reflect on the effect of strength of ties among a local community on finding solutions to municipal problems. On the one hand, it seems that "local" city residents should be more closely tied to the urban community, and so should be more greatly sensitive to the needs of their city and more active in attempts to fulfill them. But it turns out the opposite is true. This may be explained by the "local" residents creating a commune-type living ("Gemeinschaft") that does not encompass the whole urban community-which would be impossible anyway in a large city. This means that when it comes to comprehending and solving city problems - the kinds that require a broader viewpoint and actions - they are limited to a certain extent by their localness, especially in a spatial sense, as described in Gans's classical study of communities.

On the other hand, the communities of "cosmopolitan" city residents are usually connected one way or another with the urban whole-in the same way, for example, as they are connected to some part of the global orderand so their opinions and actions are also more global. The difference in resources, both material and symbolic, between the "cosmopolitan" and "local" residents is significant in principle. The former have access to them, and even when they do not use them immediately, they are aware of the potential to do so-to be opinion makers, at least, and in such a way or another to pressure the authorities and/or influence their fellow residentsand therefore they feel more confident about their involvement in resolving urban issues. As an example of such resources, their personal networking ties allow the "cosmopolitans" to speak directly with bureaucrats, members of parliament, and businesspeople at various levels - those who have a direct influence on urban life. Moreover, they can speak concretely to these matters, including presenting specific legislative, architectural, infrastructural, or other projects. Unquestionably, a city's brand is created within or by the "cosmopolitan" milieu. But of course, just having these resources does not automatically lead to problems being solved. 
In sum, we began with the premise that globalization produces two groups of city dwellers, whose urban identity (perceiving and comprehending oneself as a resident of the city) differs significantly from one another. They are the "cosmopolitan elites," whose ties to place are relatively weak, and the "local masses," who lack the resources to change their location. Correspondingly, the main question was, "How exactly does the urban identity of these groups differ in content?" In our research, we consciously refrained from measuring the level of identification with their city, since as yet there is still no methodology developed to measure it; namely, this study did not anticipate the development of such a methodology. Therefore, the conclusions apply to the testing of the hypothesis concerning the differences between representatives of various groups insofar as ways of interpreting their own connections to the city are concerned.

The research results show that these ways really do differ. This applies to the reflections on the typical "true" resident of their city, and also to the specificity of their ties to the city and to "being an urbanite," as well as to ways of interpreting and involving them in the resolution of urban problems. Most of the differences, as we expected, were associated with the differences in socio-economic and socio-cultural conditions of the studied groups. But we also found differences that depended on the specificity of cities such as Kharkiv and Lviv. The results were further refined based on polling a group called "migrant workers."

The research results provide us a basis to put forward a hypothesis that the interpretation of one's own connection to the city depends not only on which group one belongs to but also on one's location (e.g., "bedroom community" vs. city centre), age, education, and on more detailed parameters and particularities of a given profession and the resulting level of involvement in "urban life" per se (cultural events, specific leisure opportunities).

An empirical evaluation of the differences shows that urban identity encompasses two aspects-the local and the global. The former emphasizes local ties, the community, and interpersonal links, while the latter is based on understanding one's city as a representative of global development processes for society, the economy, culture, technologies, etc. ${ }^{11}$

These aspects are defined by various emphases in the content

11 These emphases can be distinguished as Tönnies's "Gemeinschaft" and "Gesellschaft" (1887; Rus. trans. ed. 2002). The influence of these ways of organizing social connections into values overall, and particularly into educational values, means, and results in institutions of higher learning, were traced in my earlier work (Musiyezdov, "Razlichiia v stiliakh"). 
interpretation of what is a city and what is a city dweller, depending on the experience and ways of involvement of residents in urban life. ${ }^{12}$ Given that we are speaking of perceptions which form the basis of identifying oneself with a city, urban identity should be treated not like a territorial concept but a cultural one, and considered as an "imagined community" (Anderson). Hence, a city is not constituted as an "urban community" or "assembly"[13] but as a set of communities that consider the city to be "theirs" and defend their own "right to the city" (viz Henri Lefebvre)-based on their own image of the world, which depends on their social, cultural, economic, and other conditions, with each of them considering their image and their interpretation of the city to be the "true" one (Musiyezdov, "Gorod i identychnost'”).

This situation becomes more difficult as informational and communicational technologies present significant obstacles to the formation of urban identity. They do not, in fact, facilitate greater communication between representatives of various urban communities; rather, due to the potential for selective communication, they provoke fragmentation and isolation among them-which engenders mutual fear, the erection of boundaries, reductions in the number and significance of urban public spaces, etc. On the other hand, while new technologies do provoke the production of differences between groups within a city, they also create the possibility of building new forms of collectivity. Either way, the existence of these new identities in general, and urban identities in particular, should be the subject of further research.

As mentioned above, the realities of modern (or, more accurately, postmodern) society are altogether such that the links between communities and territories have become problematic, and especially as they increasingly become a nexus of interpretations-rather than as perfectly objective point of departure for the existence of communities, as was earlier believed. Thus, cities have become not only territories, infrastructures, or communities but cultural perceptions, images, brands, etc.-entities that exert their own influence, particularly on the selfawareness of the city dwellers, which is to say, on urban identity. The differences in images or perceptions of their city in various communities contribute to the existence of different urban identities in any one given city.

This research can be considered one of the first attempts to study this subject matter; it has been shown that the described processes apply to Ukrainian cities as well; therefore we must focus our attention on the necessity of considering them through the prism of ideas concerning the

\footnotetext{
${ }^{12}$ It should be noted that the point is about emphases, which often co-exist, not about mutually exclusive perceptions.

13 [The well-known Ukrainian term is "hromada."-Trans.]
} 
postmodern city. 14 Certainly, no city can be interpreted as wholly postmodern-rather we may speak of a combination, in virtually every city, of modern, postmodern, and even premodern elements. In this context, an area of research that addresses postmodern features of modern Ukrainian urban culture overall can be considered as having a great deal of potential.

\section{INTERVIEW GUIDE}

Do you consider yourself a Lvivian?15

Why? What situations prompt this feeling, or reinforce it?

What does it mean to be a "Lvivian"?

Who is a "true Lvivian"? Try to define such a person: What is their occupation? What do they consider to be important or unimportant? How do they spend their leisure time? What do they enjoy or dislike?

Taking into consideration the above, please state to what extent you personally conform to the image of a "true Lvivian"? What do you do as a true Lvivian?

- Are you employed as a true Lvivian? / What does your job consist of?

- Do you spend your leisure time as a true Lvivian? / How do you usually spend your free time?

What is your profession according to your education? What is your job (and is it in Lviv or outside Lviv $\left.{ }^{16}\right)$ ?

How easy or difficult is it for you to find a job you would like in another place, and where exactly (in Ukraine, abroad, in a rural area)?

Would you like to live in another place? Why? Where exactly (Which country? City? Outside a city?) What do you need to do this?

Can you compare life in your city with how people live in other cities where you have been or that you know well? If yes, then what is common to life in these cities?

Can you compare Lvivians with other cities' residents? If yes, then which

14 For example, see Davis; Dear and Flusty; Gottdiener; and Soja, "Taking Los Angeles" and Postmetropolis.

15 Analogous questions were given to the Kharkivians.

16 This was a separate clarification question given to the "migrant workers." 
cities? Which other cities' residents are Lvivians most similar to, and how?

What does it mean to you to be a "city dweller"?

What exactly do you like and dislike about life in the city?

Which problems in your city are you most concerned about? And who should be solving them?

If you yourself participate in solving urban problems, what exactly do you do?

\section{Works Cited}

Anderson, Benedykt (Benedict Anderson). Uiavleni spil'noty: Mirkuvannia shchodo pokhodzhennia i poshyrennia natsionalizmu. Translated by V. Morozov, Krytyka, 2001. (Translation of Imagined Communities: Reflections on the Origin and Spread of Nationalism. 2nd ed., Verso, 1991).

Bauman, Zigmunt (Zygmunt Bauman). Gorod strakhov, gorod nadezhd. Translated by A. Smirnova, Logos, vol. 66, no. 3, 2008, pp. 24-53. (Translation of City of Fears, City of Hopes. Goldsmiths College, 2003).

Baumeister, Roy F. Identity: Cultural Change and Struggle for Self. Oxford UP, 1986.

Castells, Manuel. The Power of Identity. Vol. 2, The Information Age: Economy, Society and Culture. Blackwell, 1997.

Clark, Terry Nichols, editor. The City As an Entertainment Machine. Elsevier, 2004.

Davis, Mike. City of Quartz: Excavating the Future in Los Angeles. Macmillan, 1992.

Dear, Michael, and Steven Flusty. "The Postmodern Urban Condition." Spaces of Culture: City, Nation, World, edited by Mike Featherstone and Scott Lash, Sage Publications, 1999, pp. 64-85.

Department for Digital, Culture, Media, and Sport (UK). Creative Industries Economic Estimates (Experimental Statistics) Full Statistical Release. Department for Culture, Media, and Sport (UK), 9 Dec. 2010. https://www.gov.uk/government/uploads/system/uploads/attachment_data Lfile/77514/CIEE_Full_Release_Dec2010.pdf. Accessed 10 Jan. 2020.

---. Creative Industries Mapping Document 2001. 2nd ed., 2001. https://assets.publishing.service.gov.uk/government/uploads/system/upload s/attachment data/file/183544/2001part1-foreword2001.pdf. Accessed 10 Jan. 2020.

Florida, Richard. Kreativnyi klass: liudi, kotorye meniaiut budushchee. Translated by A. Konstantinov, Klassika-XXI, 2005. (Translation of The Rise of the Creative Class, and How It's Transforming Work, Leisure, and Everyday Life. Basic Books, 2002).

Gans, Herbert J. The Urban Villagers: Group and Class in the Life of Italian-Americans. Free Press, 1962.

Giddens, Anthony. Modernity and Self-Identity: Selfand Society in the Late Modern Age. Polity Press, 1991. 
Gnedovskii, Vasilii. "Sovremennye problemy razvitia postindustrial'nogo obshchestva v gorodakh SShA i Evropy." Ekologiia kul'tury: Informatsionnyi biulleten', no. 2(36), 2005. Also available on-line: https://www.cultura.kh.ua/images/stories/document/invest/Gnedovskiy.doc. Accessed 11 Jan. 2020.

Gottdiener, Mark. The New Urban Sociology. Westview Press, 2010.

Hlibovyts'kyi, Ievhen, and Iaroslav Hrytsak. "Tsinnosti Ukrainy." TEDxKyiv, 2011. http://www.youtube.com/watch?v=noIW9A8V7WE. Accessed 11 Jan. 2020.

Kastel's, M (Manuel Castells). Informatsionnaia epokha: ekonomika, obshchestvo i kul'tura. Translated and edited by O. I. Shkaratan, Higher Economic School, 2000. (Translation of The Rise of the Network Society. Vol. 1, The Information Age: Economy, Society, and Culture, Blackwell, 1989.)

---. "Rekonstruktsiia sotsial'nogo smysla v prostranstve potokov." Informatsionnyi gorod. Informatsionnaia tekhnologiia, ekonomicheskoe restruktuirovanie $i$ regional'no-gorodskoi protsess, by Manuel' Kastel's (Manuel Castells), translated by V. V. Vagin, Urban Sociology, 14 May 2009. http://lesurbanistes.blogspot.com/2009/05/blog-post 14.html. Accessed 10 Jan. 2020.

Kononov, Il'ia. "Prostranstvennyi povorot v sotsiologicheskoi teorii." Metodolohiia, teoriia ta praktyka sotsiolohichnoho analizu suchasnoho suspil'stva, vol. 19, Kharkivs'kyi natsional'nyi universytet imeni V. N. Karazina, 2013, pp. 151-57.

Kutsenko, Ol'ga. "Rost 'novogo klassa': vliianie faktora obrazovaniia na sotsial'noe razdelenie." Suspil'stvo nerivnykh: Klasovyi analiz nerivnostei v suchasnomu suspil'stvi: Sproby zakhidnoi sotsiolohii, Vyd. tsentr Kharkiv. un-tu, 2000, pp. 20037.

Musiezdov, Aleksei (Oleksii Musiiezdov [Oleksiy Musiyezdov]). "Gorod i identychnost'." My Sociology: Sotsiologicheskie i ne ochen' stat'i i teksty, 2014. http://socresource.blogspot.com/2014/10/blog-post.html.

---. "An Identity of Kharkiv: A Concept of the City and its History as Identification Factors." ece-urban (Online Publication Series of the Centre for Urban History of East Central Europe, Lviv), vol 5, 2009. http://www.lvivcenter.org/download.php?newsid=1074\&fileno=2. Accessed 11 Jan. 2020.

---. "Identyfikatsiia Kharkova: dosvid konstruiuvannia obrazu mista." Problemy istorychnoi urbanistyky, Special Issue of Skhid/Zakhid: istoryko-kul'turolohichnyi zbirnyk, vol. 15, 2011, pp. 217-34.

---. "Razlichiia v stiliakh obucheniia mezhdu 'gorodskimi' i 'sel'skimi' studentami." Metodolohiia, teoriia ta praktyka sotsiolohichnoho analizu suchasnoho suspil'stva, vol. 12, Kharkiv University, 2006, pp. 420-27.

Sereda, Viktoriia. "Lviv"ianyn'-okrema identychnist' chy mistse propysky." Sotsiolohichni doslidzhennia suchasnoho suspil'stva: metodolohiia, teoriia, metody, Special Issue of Visnyk Kharkivs'koho natsional'noho universytetu imeni V. N. Karazina, vol. 795, 2008, pp. 94-98.

Soja, Edward W. Postmetropolis: Critical Studies of Cities and Regions. Oxford Blackwell, 2000.

---. "Taking Los Angeles Apart: Some Fragments of a Critical Human Geography." Environment and Planning D: Society and Space, vol. 4, 1986, pp. 255-72. DOI: $10.1068 / \mathrm{d} 040255$ 
Tennis, Ferdinand (Ferdinand Tönnies). Obshchnost' i obshchestvo: osnovnye poniatiia chistoi sotsiologii. Vladimir Dahl, 2002. (Translation of Gemeinschaft und Gesellschaft: Grundbegriffe der reinen Soziologie. 8th ed., Buske, 1935 [C1887]).

Trubina, Elena. Gorod v teorii: opyty osmysleniia prostranstva. Novoe literaturnoe obozrenie, 2010.

---. "Povorot k prostranstvu: mezhdistsiplinarnoe dvizhenie i slozhnosti ego populiarizatsii." Politicheskaia kontseptologiia, vol. 4, 2011, pp. 34-49.

Vagin, Vladimir. Sotsiologiia goroda. Uchebnaia literatura, 2003. Available on-line at http://www.gumer.info/bibliotek Buks/Sociolog/Vagin/04.php. Accessed 17 Jan. 2020.

Zakutii, I. "Ukrains'kyi P"iemont: evoliutsiia idei." Kopychyntsi ta okolytsi (kopychyntsi.com.ua), $\quad 2 \quad$ May 2011. https://kopychyntsi.com.ua/archive/polityka/ukrains-kyy-piemontevoliutsiia-idei/. Accessed 11 Jan. 2020.

Znaniecki, Florian. Miasto $w$ świadomosci jego obywateli. Wydawnictwo Polskiego Instytutu Socjologicznego, 1931.

Zukin, Sharon. Naked City: The Death and Life of Authentic Urban Places. Oxford UP, 2010. 